\title{
PEMBELAJARAN KAIDAH BAHASA INDONESIA DAN KETERAMPILAN BERBAHASA SECARA TERPADU DENGAN PENDEKATAN FOCUS ON FORM PADA SISWA SEKOLAH MENENGAH PERTAMA
}

\author{
Sumarwati, Atikah Anindyarini, dan Amir Fuady \\ FKIP Universitas Sebelas Maret \\ email: watik_uns@ymail.com
}

\begin{abstract}
Abstrak
Penelitian ini bertujuan: (1) memetakan kebutuhan siswa untuk meningkatkan pemahaman terhadap tata bahasa, (2) memetakan kebutuhan guru untuk mengatasi rendahnya pemahaman siswa terhadap tata bahasa, dan (3) merancang model pembelajaran tata bahasa. Penelitian adalah penelitian dan pengembangan. Subjek penelitian adalah siswa kelas VIII dari 12 sekolah menengah pertama. Hasil penelitian menunjukkan bahwa (1) sebagian besar siswa menyatakan perlunya pengajaran dan pembelajaran tata bahasa Indonesia yang lebih intensif; (2) mereka menyatakan perlunya mempelajari semua komponen tata bahasa secara intensif; (3) guru tidak menyampaikan pengetahuan tata bahasa di luar standar kompetensi; (4) masalah utama yang dihadapi guru dalam mengajarkan tata bahasa dengan mengintegrasikan ke semua keterampilan berbahasa meliputi penyiapan bahan, pemilihan strategi, dan penilaian; dan (5) model pengajaran untuk menerapkan "focus on form" meliputi proses instruksional, umpan balik interaktif, peningkatan pemahaman teks, pembelajaran berbasis tugas, tugas kolaboratif, dan pendekatan berbasis wacana.
\end{abstract}

Kata kunci: kaidah bahasa Indonesia, pembelajaran keterampilan bahasa, kebutuhan siswa, kebutuhan guru

\section{INTEGRATED LEARNING OF INDONESIAN GRAMMATICAL RULES AND SKILLS THROUGH THE FOCUS-ON-FORM APPROACH FOR JUNIOR HIGH SCHOOL STUDENTS}

\begin{abstract}
This study aims to: (1) map the students' needs to enhance their understanding of grammar (2) map the teachers' needs to overcome students' low understanding of grammar, and (3) design a grammar teaching model. This was a research and development study. The research subjects were Grade VIII students of twelve junior high schools. The results indicate that (1) the majority of students say that it is necessary to have more intensive teaching and learning of Indonesian grammar; (2) they state that it is necessary to learn all the components of grammar more intensively; (3) all teachers do not deliver the knowledge about grammar beyond the competency standard; (4) the main problems that teachers experience in teaching grammar through an integration of all language skills are materials preparation, strategy selection, and assessment; and (5) the teaching model to implement "focus on form" includes instructional process, interactive feedback, text comprehension enhancement, task-based instruction, collaborative tasks, and discoursebased approach.
\end{abstract}

Keywords: Indonesian grammatical rules, language skill learning, students' needs, teachers' needs

\section{PENDAHULUAN}

Salah satu tujuan pembelajaran bahasa Indonesia di sekolah adalah meningkatkan kemampuan siswa untuk berkomunikasi dalam bahasa Indonesia dengan baik dan benar, secara lisan maupun tulis. Penger- 
tian baik adalah menggunakan bahasa sesuai situasi dan benar adalah sesuai kaidah, sehingga pada situasi nonformal memakai bahasa tidak baku dan pada situasi formal memakai bahasa baku.

Secara formal, pelajaran Bahasa Indonesia diberikan mulai kelas 1 SD sehingga penguasaan bahasa setelah tamat SD berada pada taraf semenjana (Suyatno, 2010). Karena itu, siswa yang duduk di SMP seharusnya telah mampu berkomunikasi lisan maupun tulis secara baik dan benar. Akan tetapi, kenyataan di lapangan menunjukkan siswa masih menghadapi masalah dalam menggunakan bahasa Indonesia, khususnya berbahasa ragam baku. Masalah yang dimaksud adalah banyaknya kesalahan bahasa sehingga berpengaruh terhadap kemampuannya dalam berbahasa secara formal.

Kemampuan menerapkan kaidah bahasa pada siswa sangat penting karena kurang memadainya penguasaan itu dapat menjadi hambatan dalam berkomunikasi. Ini disebabkan banyaknya kesalahan bahasa menjadikan ide yang disampaikan sulit dipahami audien dan bisa memunculkan salah interpretasi. Bahkan Myhill \& Jones (2007: 332) menyatakan bahwa menulis dengan banyak kesalahan bahasa merupakan kegiatan yang sia-sia karena hasil tulisannya tidak akan dibaca orang. Sebaliknya, tulisan dengan kesalahan bahasa minimal memungkinkan pembaca dapat memahami isinya secara optimal. Oleh karena itu, sudah seharusnyalah dilakukan upaya agar siswa melakukan kesalahan bahasa seminimal mungkin.

Menyikapi kondisi di atas, peneliti terdorong untuk mengembangkan model pembelajaran keterampilan berbahasa (menyimak, berbicara, membaca, menulis) yang di dalamnya juga membahas kaidah bahasa, yaitu pendekatan "focus on form" yang merupakan aplikasi dari pendekatan komunikatif dengan konsep yang benar. Adapun yang diterapkan selama ini adalah hanya focus on meaning. Penerapan pendekatan "focus on form" dilakukan dengan mengaitkan materi kaidah bahasa dalam konteks pemakaian bahasa yang alamiah atau otentik sehingga pengenalan tata bahasa bersifat bottom-up (Chen, 2005). Dengan dilatih mengidentifikasi kaidah pemakaian bahasa dalam teks yang sedang menjadi topik pembelajaran, memungkinkan tumbuhnya kepekaan siswa dalam mengenali bentuk-bentuk bahasa yang setipe, termasuk bentuk kesalahan berbahasa.

Tujuan umum penelitian ini adalah untuk mengembangkan model pembelajaran kaidah bahasa Indonesia pada siswa SMP dengan pendekatan "focus on form". Adapun tujuan tahun pertama adalah untuk: (1) memetakan kebutuhan guru dalam melaksanakan pembelajaran keterampilan berbahasa, khususnya membaca dan menulis, yang dapat mengatasi rendahnya penguasaan kaidah bahasa Indonesia pada siswa, (2) memetakan kebutuhan siswa terhadap pelaksanaan pembelajaran keterampilan berbahasa yang dapat meningkatkan penguasaannya terhadap kaidah bahasa Indonesia, dan (3) mengembangkan desain model pembelajaran kaidah bahasa Indonesia dengan pendekatan "focus on form",

Selama ini, sejak diberlakukannya Kurikulum 1984, pendekatan pembelajaran yang diterapkan dalam pembelajaran bahasa Indonesia adalah pendekatan komunikatif. Adapun teori bahasa yang secara khusus dianggap sebagai dasar pengembangan pendekatan komunikatif adalah teori bahasa sebagai komunikasi. Dalam teori itu, bahasa dilihat lebih dari sekedar sistem kaidah gramatikal, tetapi sebagai sebuah sistem komunikasi. Ini dapat dikaitkan dengan ada kalanya sebuah struktur bahasa yang gramatikal tidak mudah dipahami. Ini menunjukkan pemakaian bahasa tersebut tidak komunikatif bagi audien, sehingga pesan yang ditangkap tidak seperti yang dimaksud pemakai bahasa. Karenanya, untuk pe- 
makaian bahasa seperti itu disebut pendekatan komunikatif yang kemudian menjadi label untuk pendekatan pembelajarannya (Nuftall lewat Nurkamto, 2003:565).

Pada perkembangannya, para peneliti menemukan adanya salah konsep dalam penerapan pendekatan komunikatif sehingga menimbulkan penyimpangan yang berdampak pada penguasaan bahasa oleh para pelajar. Konsep pembelajaran dengan pendekatan komunikatif yang semula bertujuan agar pemakaian bahasa diarahkan pada aspek kegramatikalan dan kebermaknaan, menjadi hanya mementingkan aspek kebermaknaan dan mengabaikan kegramatikalan. Oleh karena itulah oleh Basturkmen, Loewen \& Ellis (2002) pembelajaran dengan pendekatan komunikatif disebut sebagai pembelajaran yang meaning-focused atau focus on meaning.

Pada dasarnya pendekatan focus on form merupakan salah satu pendekatan pembelajaran yang berada di bawah paradigma konstruktivisme, yaitu memberikan keleluasaan pada pelajar untuk mengkonstruksi pengetahuannya berdasarkan fenomena yang sedang dipelajari (Doughty \& Wlliam, 1998:13). Adapun Hayashi (1995:98) menyatakan bahwa pendekatan "focus on form" merupakan bagian dari pendekatan komunikatif dalam pembelajaran bahasa. Akan tetapi, Basturkmen, Loewen \& Ellis (2002) berpendapat bahwa pendekatan "focus on form" diadakan sebagai reaksi terhadap penyimpangan-penyimpangan dalam menerapkan pendekatan komunikatif.

Penyimpangan penerapan pendekatan komunikatif dari konsep awalnya itulah yang mendorong para pakar bahasa berupaya meluruskan kembali konsep pendekatan komunikatif, yang salah satunya adalah diadakannya pendekatan "focus on form" 'berfokus pada bentuk' (tapi tetap mementingkan makna). Dalam hal ini, penggunaan istilah "focus on form" semata-mata hanya ditujukan untuk membedakan dengan focus on meaning sehingga pengertiannya tidak dilakukan secara harfiah, yakni hanya mengutamakan bentuk. Dengan demikian, keberadaan "focus on form" versi Basturkmen, Loewen \& Ellis (2002) pada dasarnya sama dengan Hayashi (1995), yakni merupakan realisasi dari pendekatan komunikatif dalam pembelajaran tata bahasa.

Pendekatan "focus on form" timbul bertalian dengan upaya meluruskan penerapan pendekatan komunikatif pada pemakaian bahasa. Tujuan pembelajarannya adalah mengarahkan pemakaian bahasa pada fungsi-fungsi komunikasi dasar (seperti permintaan maaf, penjelasan, undangan). Pembelajar bahasa perlu mengetahui dan menekankan cara-cara dalam bentuk gramatikal tertentu yang mungkin digunakan untuk mengungkapkan fungsi-fungsi tersebut dengan tepat (Loewen, 2003:316).

Menurut Basturkmen, Loewen \& Ellis (2002), pembelajaran tata bahasa dengan pendekatan "focus on form" dapat dibedakan menjadi 2 tipe, yaitu: (1) "focus on form" terprogram atau planned "focus on form" dan (2) "focus on form" tidak terprogram atau incidental "focus on form". Yang dimaksud dengan "focus on form" terprogram adalah pembelajaran tata bahasa dengan materi yang telah direncanakan, sesuai dengan silabusnya. Teks yang menjadi sumber/media pembelajaran dipilihkan yang memuat bentuk-bentuk linguistik yang hendak dipelajari. Tujuan utama pembelajarannya adalah menanamkan konsep tata bahasa melalui konteks yang jelas. Adapun "focus on form" insidental pembelajaran berbahasa yang ada kalanya diselingi dengan pemberian kaidah tata bahasa. Pada pembelajaran ini, yang menjadi tujuan utamanya adalah belajar berbahasa untuk berkomunikasi sehingga mempelajari kaidah bahasa dilakukan seperti time out, yakni hanya pada struktur tertentu jika siswa menghadapi kesulitan 
terhadap kaidahnya. Untuk penelitian ini, pendekatan yang akan diterapkan adalah "focus on form" terprogram karena tujuan utamanya adalah menyampaikan materi kaidah bahasa.

\section{METODE}

Penelitian ini merupakan penelitian pengembangan (Research and Development) yang dilakukan di daerah eks Karesidenan Surakarta yang juga merepresentasikan Provinsi Jawa Tengah dengan mayoritas penduduknya menggunakan bahasa Indonesia sebagai bahasa kedua dan bahasa Jawa sebagai bahasa pertama, sehingga seringkali terjadi pencampuran kaidah bahasa Indonesia dan Jawa pada siswa. Daerah tersebut adalah Kota Surakarta dan Kabupaten Karanganyar. Selanjutnya, dari masing-masing daerah akan diambil 6 SMP negeri dan swasta dengan rincian 3 SMP berkualifikasi baik dan 3 SMP berkualifikasi kurang baik.

Pengembangan model pembelajaran di sini merupakan model prosedural, yakni berkaitan dengan langkah-langkah dalam pembelajaran kaidah bahasa Indonesia dengan pendekatan "focus on form". Model pengembangan yang diterapkan mengacu pada model yang diformulasi Echevarria, Short \& Powers (2006). Formulasi model tersebut didasari oleh The ADDIE Model yang visualisasinya dapat dilihat pada Gambar 1.

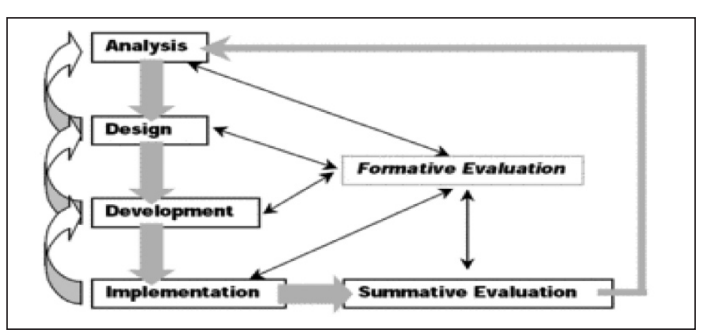

Gambar 1. Proses Pengembangan The ADDIE Model

(Echevarria, Short \& Powers, 2006:201)

Deskripsi lima kegiatan di atas sebagai berikut. Pertama, analysis: menganalisis problem dalam pembelajaran. Kedua, design: membuat rancangan rencana pembelajaran. Ketiga, development: membuat blueprint 'contoh' pelaksanaan pembelajaran. Keempat, implementation: melakukan uji lapangan. Kelima, evaluation: melakukan evaluasi yang meliputi evaluasi formatif atau mengevaluasi hasil yang dicapai setiap fase dan evaluasi sumatif atau mengevaluasi hasil implementasi.

Penentuan sekolah (SMP) negeri dan swasta yang menjadi lokasi penelitian pada tiap daerah dilakukan secara purposive sampling. Adapun yang menjadi dasar pengambilannya adalah proporsi sekolah negeri dan swasta di daerah tersebut. Maksudnya, jumlah SMP negeri dan swasta yang diambil disesuaikan dengan perbandingan jumlah keseluruhan SMP yang ada. Selain itu, karakteristik siswa (jumlah dan kualitas input) dan guru (jenjang pendidikan dan pengalaman mengajar) juga menjadi dasar pemilihan lokasi penelitian. Diupayakan sekolah-sekolah yang dipilih memiliki karakteristik siswa dan guru yang setara.

Sumber data penelitian ini meliputi informan, peristiwa, dan dokumen. Informan yaitu guru bahasa Indonesia dan siswa kelas VIII di 12 SMP Untuk mengidentifikasi kebutuhan guru dalam mengatasi rendahnya penguasaan kaidah bahasa Indonesia pada siswa dan kebutuhan siswa untuk meningkatkan penguasaannya terhadap kaidah bahasa, tidak tertutup kemungkinan diperlukannya informasi dari informan lain seperti kepala sekolah, guru bidang studi lain, dan petugas perpustakaan. Peristiwa, yaitu: (1) proses pembelajaran bahasa Indonesia (menyimak, berbicara, membaca, dan menulis) yang biasa dilakukan guru dan (2) prototipe model pelaksanaan pembelajaran kaidah bahasa Indonesia dengan pendekatan "focus on form". Sumber data dokumen akan digunakan pula untuk melengkapi informasi tentang kebutuhan guru dan siswa. Yang dimaksud doku- 
men di sini adalah (1) kurikulum Bahasa Indonesia, (2) perangkat pembelajaran yang digunakan guru selama ini, dan (3) prototipe model perangkat pembelajaran yang dikembangkan berbasis pendekatan "focus on form".

Berkaitan dengan tujuan penelitian tahun pertama dan sumber data yang diperlukan, pengumpulan data dilakukan dengan teknik sebagai berikut ini. Wawancara mendalam dilakukan terhadap guru untuk mengidentifikasi kebutuhannya dalam rangka mengatasi rendahnya penguasaan kaidah bahasa Indonesia pada siswa. Wawancara mendalam, yaitu secara individual, juga dilakukan terhadap siswa untuk mengidentifikasi kebutuhannya dalam rangka meningkatkan penguasaannya terhadap kaidah bahasa Indonesia. Selain wawancara mendalam, pengumpulan data terhadap siswa juga dilakukan secara klasikal, yaitu melalui focus group discussion (FGD). Angket atau daftar pertanyaan yang direspon guru dan siswa secara tertulis untuk melengkapi data dari wawancara dan FGD. Observasi dilakukan terhadap proses belajar mengajar Bahasa Indonesia untuk mengidentifikasi aktivitas guru dan siswa yang mendukung dan kurang mendukung dilakukannya pembelajaran kaidah bahasa Indonesia. Analisis dokumen dilakukan terhadap perangkat pembelajaran yang biasa dibuat guru dan hasil pekerjaan siswa (tes atau karangan). Selain itu, analisis dokumen juga dilakukan pada video rekaman prototipe model pelaksanaan pembelajaran kaidah bahasa Indonesia dengan pendekatan "focus on form".

Untuk memperoleh data yang benar dan tepercaya dilakukan uji validitas data dengan beberapa teknik, yaitu triangulasi sumber data, triangulasi metode, dan member check. Triangulasi sumber data, yakni melakukan konfirmasi kebenaran suatu informasi dari satu sumber dengan sumber lainnya. Misalnya data yang berkaitan dengan informasi tentang prosedur pembelajaran Bahasa Indonesia yang diperoleh dari guru dikonfirmasi pada beberapa siswa. Triangulasi metode, yaitu menguji kebenaran informasi yang diperoleh dari metode pengumpulan data yang satu dengan metode lainnya. Misalnya informasi tentang kesulitan siswa dalam menerapkan kaidah bahasa yang diperoleh dengan metode wawancara pada siswa dikonfirmasi dengan pemakaian bahasa pada karangannya (metode analisis dokumen). Member check, yaitu melakukan pengecekan kebenaran data yang diperoleh satu peneliti dengan melakukan konfirmasi pada anggota peneliti lain.

Data yang terkumpul selanjutnya dianalisis secara kuantitatif dan kualitatif. Analisis data kuantitatif dilakukan dengan teknik statistik sederhana yaitu menghitung frekuensi dan persentase. Hasil analisis tersebut disajikan dalam tabel-tabel sehingga mudah dibaca dan diinterpretasikan. Analisis kualitatif dilakukan dengan model analisis interaktif yang mencakup aktivitas reduksi data, displai data, dan penarikan kesimpulan atau verifikasi.

\section{HASIL DAN PEMBAHASAN Pelaksanaan Pembelajaran Kaidah Ba- hasa Indonesia}

Hasil analisis data yang dideskripsikan pada Gambar 2 menunjukkan bahwa materi kaidah bahasa Indonesia belum mendapat perhatian dari guru. Berdasarkan Gambar 2 dan hasil wawancara dengan 20 guru SMP dapat dinyatakan halhal sebegai berikut: (1) pembahasan tidak banyak dilakukan pada pembelajaran keterampilan mendengarkan, membaca dan menulis, (2) pembahasan kaidah pada keterampilan berbicara terbatas pada pelafalan kata, (3) pembahasan kaidah pada pembelajaran keterampilan mendengarkan dan membaca terbatas pada kata-kata baru/sulit. Secara umum dapat disimpulkan bahwa kaidah bahasa dan keterampil- 
an berbahasa belum diajarkan secara terpadu.

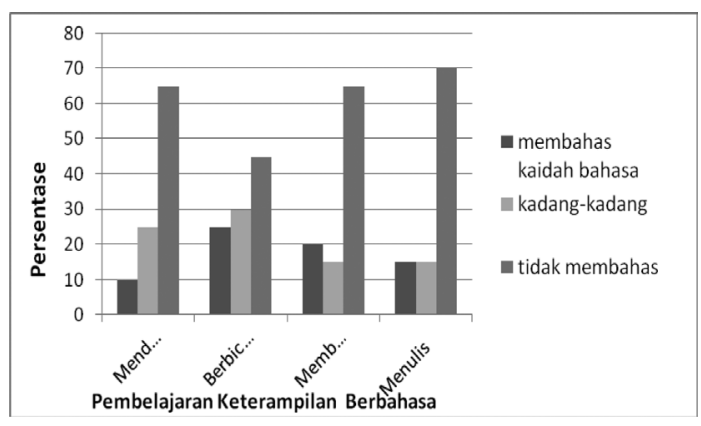

Gambar 2. Pembahasan Kaidah dalam

Pembelajaran Keterampilan Berbahasa

Berkaitan dengan permasalahan di atas, tentu ada banyak faktor yang menjadi penyebab guru tidak member perhatian terhadap penyampaian materi kaidah bahasa dalam pembelajaran keterampilan bahasa. Dari hasil analisis data diperoleh informasi bahwa faktor yang berkaitan dengan masalah-masalah yang termuat pada Gambar 3.

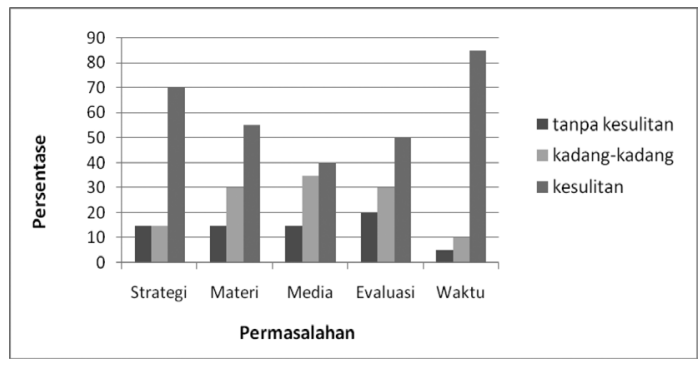

Gambar 3. Permasalahan dalam

Pembelajaran Kaidah Bahasa Indonesia

Berdasarkan Gambar 3 dapat disimpulkan bahwa : (1) guru kesulitan memilih dan menerapkan strategi/metode pembelajaran yang memungkinkan dilakukannya pembelajaran kaidah bahasa dan keterampilan berbahasa secara integratif, (2) kesulitan pengadaan materi terutama kaidah pilihan kata dan struktur kalimat dan wacana yang memuat contoh-contoh kesalahan bahasa pada aspek pilihan kata dan struktur kalimat, (3) kesulitan pengadaan media berupa rekaman bahasa lisan dan teks tertulis yang memuat model pemakaian bahasa yang bisa menjadi bahan analisis bagi siswa, terutama pada pembelajaran keterampilan mendengarkan, (4) kesulitan evaluasi terutama dalam pembuatan soal pada pembelajaran mendengarkan dan membaca dan mengoreksi karangan, dan (5) guru mengalami kesulitan dalam pembagian waktu untuk mengintegrasikan pembelajaran kaidah bahasa dan keterampilan bahasa.

Pada Kurikulum 2006 SMP, pembelajaran bahasa Indonesia diarahkan untuk meningkatkan kemampuan peserta didik untuk berkomunikasi dalam bahasa Indonesia dengan baik dan benar, baik secara lisan maupun tulis, serta menumbuhkan apresiasi terhadap hasil karya kesastraan manusia Indonesia. Adapun ruang lingkup mata pelajaran bahasa Indonesia mencakup komponen kemampuan berbahasa dan kemampuan bersastra meliputi aspek: (1) menyimak atau mendengarkan, (2) berbicara, (3) membaca, dan (4) menulis. Namun demikian, dalam pembelajaran, aktivitas-aktivitas tersebut sedapat mungkin disajikan secara terpadu. Pembelajaran mendengarkan bisa dipadukan dengan menulis/berbicara, pembelajaran menulis dipadukan dengan membaca/ mendengarkan/berbicara begitu halnya dengan pembelajaran membaca yang bisa dipadukan dengan berbicara atau menulis.

Keterpaduan juga diberlakukan pada materi kaidah bahasa yang pembelajarannya masuk pada aktivitas berbahasa. Kompetensi dasar yang secara ekplisit berkaitan dengan materi kaidah bahasa meliputi KD sebagai berikut. Pertama, Kelas VII, terdapat 35 KD dan yang berkaitan dengan materi kaidah bahasa ada $3 \mathrm{KD}$, yaitu: (a) menceritakan pengalaman yang paling mengesankan dengan menggunakan pilihan kata dan kalimat efektif, (b) menulis teks pengumuman dengan bahasa yang efektif, baik dan benar, dan (c) menulis teks pengumum- 
an dengan bahasa yang efektif, baik dan benar. Kedua, kelas VIII, terdapat 39 KD dengan $5 \mathrm{KD}$ tentang kaidah bahasa, yaitu meliputi: (a) menyampaikan laporan secara lisan dengan bahasa yang baik dan benar, (b) menulis laporan dengan menggunakan bahasa yang baik dan benar, (c) membawakan acara dengan bahasa yang baik dan benar, serta santun, (d) menulis teks pengumuman dengan bahasa yang efektif, baik dan benar, dan (e) menulis pesan singkat sesuai dengan isi dengan menggunakan kalimat efektif dan bahasa yang santun. Ketiga, kelas IX, mencakup $35 \mathrm{KD}$ tetapi hanya ada $1 \mathrm{KD}$ tentang kaidah bahasa, yaitu: (a) Menyunting karangan dengan berpedoman pada ketepatan ejaan, tanda baca, pilihan kata, keefektifan kalimat, keterpaduan paragraf, dan kebulatan wacana

Berdasarakan uraian di atas, dapat disimpulkan bahwa materi kaidah bahasa untuk SMP yang secara eksplisit dinyatakan dalam KD tidak banyak, yaitu hanya 9 dari 109 KD atau 8,3\%. Namun demikian, tidak berarti materi kaidah bahasa hanya sebatas pada KD tersebut karena melalui banyak KD lain, materi itu dapat disajikan (Sutama, 2008). Artinya selain pada 9 KD itu, kaidah bahasa dapat dikenalkan dan dilatihkan kepada siswa pada saat mereka menggunakannya ketika praktik mendengarkan, berbicara, membaca, dan menulis. Akan tetapi, pada umumnya guru Bahasa Indonesia belum melaksanakan pengintegrasian materi kaidah bahasa dalam pembelajaran keterampilan bahasa. Bahkan ketika melakukan pembelajaran dengan KD tentang kaidah bahasa, materi tersebut tidak dibahas dan hanya memfokuskan pada peningkatan kompetensi keterampilan berbahasa siswa.

Selanjutnya, kebutuhan siswa untuk meningkatkan penguasaan kaidah bahasa Indonesia sebagai berikut. Pertama, pemberian koreksi dan contoh-contoh pemakaian bahasa yang salah Kedua, bimbingan pada tahap penyuntingan de- ngan memberi tanda koreksi pada tulisan yang salah secara bertahap (tidak pada semua aspek kesalahan sekaligus). Ketiga, pembahasan kaidah kalimat diperbanyak dan kesempatan berlatih menemukan keselahan dan membetulkan kesalahan bahasa. Keempat, pada kegiatan berbahasa yang dilakukan siswa, guru diharapkan memberikan koreksi. Kelima, pada pembelajaran keterampilan bahasa secara reseptif, guru memberikan contoh-contoh pemakaian bahasa yang salah. Keenam, pada pembelajaran menulis, guru memberikan bimbingan pada tahap penyuntingan dengan memberi tanda koreksi pada tulisan yang salah secara bertahap (tidak pada semua aspek kesalahan sekaligus). Ketujuh, pembahasan kaidah kalimat diperbanyak (bukan hanya ejaan dan kata). Kedelapan, ada kesempatan berlatih menemukan keselahan dan membetulkan kesalahan bahasa.

Banyaknya kesalahan bahasa siswa SMP cukup merisaukan. Kesalahan dalam menulis pada komponen pilihan kata dan penyusunan kalimat, pasti terjadi juga dalam berbicara. Misalnya pemakaian kata seperti cuma, ngerti, kayak, dan disebabkan karena, jika digunakan dalam bahasa tulis pasti digunakan juga pada bahasa lisan, atau sebaliknya. Sudah pasti hal itu selain berpengaruh pada kemampuan menulis, juga pada berbicara, bahkan berdampak pada kemampuan menyunting bahasa. Oleh Hendrickson (1981: 12) fenomena itu disebut "fosilisasi kesalahan berbahasa", dalam pengertian kesalahan telah mengendap dalam long-term memory. Jadi, kalau tidak segera diatasi, kesalahan itu akan terbawa pada waktu mereka duduk di SMA, bahkan di perguruan tinggi.

\section{Pembelajaran Kaidah Bahasa dalam Konteks Pemakaian Bahasa Otentik}

Berdasarkan hasil wawancara dengan para guru diperoleh gambaran hal-hal yang mereka butuhkan untuk melaksanakan pembelajaran kaidah berbahasa dan 
keterampilan berbahasa secara tepat adalah sebagai berikut. Pertama, strategi pembelajaran yang mengakomodasi pembelajaran terintegratif. Kedua, materi yang berupa contoh-contoh kesalahan bahasa pada aspek pilihan kata dan struktur kalimat. Ketiga, media berupa rekaman bahasa lisan \& teks tertulis yang memuat model pemakaian bahasa yang bisa menjadi bahan analisis bagi siswa. Keempat, contoh lembar kerja siswa yang memungkinkan dilakukannya evaluasi terhadap pembelajaran secara integratif .

Berdasarkan peta kebutuhan guru dan siswa serta dengan berlandaskan kajian teori dan hasil penelitian relevan dapat dirumuskan rambu-rambu desain model pembelajaran kaidah bahasa dan keterampilan berbahasa secara terpadu berbasis "focus on form". Strategi yang diterapkan dalam pembelajaran kaidah bahasa antara lain processing instruction 'pembelajaran berorientasi proses', interactional feedback 'feedback interaksional', textual encahcement' menyunting wacana', task-based instruction 'pembelajaran berbasis tugas', dictogloss, dan discourse-based analysis 'analisis berbasis wacana'. Penjelasan masing-masing strategi tersebut sebagai berikut.

Pembelajaran yang berorientasi pada proses adalah cara menyampaikan kaidah bahasa yang diawali dengan pemfokuskan pada materi yang ditargetkan kemudian diikuti dengan diikuti latihan menggunakannya dalam praktikberbahasa (Nassaji \& Fotos, 2004:131). Pengajar tidak sekedar memberikan fakta atau konsep sebanyak-banyaknya tentang suatu kaidah bahasa, tetapi lebih terfokus pada proses sampai siswa menemukan konsep. Jadi, yang penting adalah siswa memahami penerapan kaidah tersebut, sehingga bahasa yang digunakan juga mudah dipahami. Oleh karena itulah, dari hasil penelitianya, Ellis, (2001) menyimpulkan bahwa pembelajaran berorientasi proses merupakan upaya menghubung- kan "bentuk-makna". Dalam implementasi pembelajarannya, seorang pakar pengajaran bahasa, Van Patten (2002), merekomendasikan aktivitas yang dapat dilakukan guru sebagai berikut. Pertama, guru memberikan contoh-contoh pemakaian bahasa yang memuat penerapan kaidah bahasa yang akan diajarkan (misalnya wacana deskripsi). Kedua, guru memfokuskan pembahasan pada kaidah bahasa yang ditargetkan. Ketiga, siswa membuat contoh-contoh yang relevan. Keempat, siswa dan guru mengevaluasi contoh buatan siswa. Kelima, siswa diminta membuat karangan atau bahan pidato dengan menerapkan kaidah yang telah dipelajari (misalnya menulis paragraf deskriptif)

Feedback interaksional adalah berbagai cara negosiasi dan modifikasi seperti pengulangan, permintaan klarifikasi, atau pemberian tanda cek pada pemakaian bahasa untuk meminta perhatian dan atau meminta penjelasan berkenaan dengan kaidah bahasa tertentu (Nassaji \& Fotos, 2004:132). Feedback tersebut dapat dilakukan seorang siswa kepada guru, siswa satu kepada yang lain, atau dari guru kepada siswa. Strategi ini didasarkan pada teori bahwa pemberian fokus perhatian terhadap bentuk-bentuk pemakaian bahasa tertentu dapat mendorong pelajar bahasa untuk lebih memperhatikan pemakaian bahasa sehingga akan lebih akurat dan mudah dipahami (Ellis, 2001). Salah satu contoh penerapan feedback interaksional, yaitu pada pembelajaran menulis dengan menerapkan koreksi antarteman. Langkah-langkahnya sebagai berikut: (1) siswa diminta menulis sebuah karangan, (2) siswa diminta menukarkan karangannya kepada teman, (3) dengan dipandu guru, siswa memberi tanda-tanda tertentu pada bentuk-bentuk kebahasaan yang salah, (4) siswa mengembalikan karangan temannya, dan (4) dengan berdasarkan tanda-tanda yang diberikan temannya, siswa memperbaiki pemakaian bahasanya (Nassaji \& Cumming, 2000). 
Kegiatan menyunting pemakaianbahasa pada suatu wacana adalah menemukan letak kesalahan pemakaian bahasa dan membetulkannya. Guru dapat menuliskan bagian-bagian tertentu pada wacana dengan cetak tebal, cetak miring, memberi garis bawah atau menggunakan huruf kapital sehingga menarik perhatian siswa. Hal tersebut dilakukan untuk membantu siswa menemukan kesalahan bahasa. Adapun langkah-langkah pembelajarannya sebagai berikut. Pertama, siswa diberi wacana yang di dalamnya terdapat beberapa kesalahan pemakaian bahasa (dicetak tebal atau diberi garis bawah). Kedua, siswa membaca wacana dan mengidentifikasi penyebab kesalahan bahasa. Ketiga, siswa melakukan koreksi terhadap kesalahan pemakaian bahasa. Keempat, siswa menulis ulang wacana.

Yang dimaksud dengan pembelajaran berbasis tugas adalah penyampaian materi kaidah bahasa melalui aktivitas komunikatif. Salah satu strategi adalah dengan dengan menggunakan kaidah bahasa sebagai topik pembicaraan (Fotos, 1996). Adapun caranya sebagai berikut: (1) Siswa diminta membaca wacana yang memuat aturan-aturan atau kaidah bahasa tertentu, misalnya kaidah penulisan kata serapan dan (2) Siswa diminta menyampaikan dengan kata-kata sendiri secara lisan atau dua siswa diminta bertanya jawab dengan topik kaidah bahasa yang telah dibacanya.

Secara singkat dictogloss diberi pengertian sebagai tugas menulis berdasarkan wacana yang dibacakan guru dengan menerapkan kaidah bahasa tertentu yang telah diajarkan, biasanya kaidah pemakaian kata. Langkah-langkah pembelajarannya adalah sebagai berikut. Pertama, guru membacakan wacana dua kali dengan kecepatan yang wajar sehingga siswa dapat memahami isinya. Kedua, guru menuliskan beberapa kata yang relevan dengan isi wacana di papan tulis, misalnya kata kerja berafiks me(N)-kan. Ketiga, siswa diminta berkelompok. Keempat, siswa dengan kelompoknya diminta menuliskan kembali isi wacana dengan menggunakan katakata yang telah dituliskan guru secara tepat. Kelima, siswa mempresentasikan hasil kerjanya. Keenam, guru bersama siswa mengevaluasi ketepatan pemakaian kata dalam presentasi siswa

Pembelajaran kaidah bahasa berbasis wacana salah satunya adalah menganalisis pemakaian bentuk-bentuk kebahasaan dalam wacana otentik yang dibuat siswa (Celce-Murcia \& Elite, 2005). Analisis dilakukan terhadap pemakaian bahasa siswa, misalnya surat dinas yang dibuat pada waktu pelajaran menulis. Dengan melakukan analisis terhadap bahasa siswa, contoh-contoh kesalahan pemakaian yang ditemukan siswa di bawah bimbingan guru lebih bersifat otentik dan dapat menjadi refleksi bagi siswa (Sarigul, 2005). Hal itu dilatarbelakangi pemikiran bahwa kesalahan tersebut sebenarnya bukan hal yang asingbagisiswa karenabentuk-bentuk kesalahan yang dilakukan salah satu siswa biasanya dilakukan juga oleh siswa lain (Abdolmanafi \& Branch, 2010 dan Heo, 2007). Adapun langkah-langkah dalam pembelajarannya adalah sebagai berikut. Pertama, siswa diminta mencermati pemakaian bahasa bahasa dalam surat dinas buatan salah satu siswa yang ditayangkan guru sebagai hasil pembelajaran sebelumnya. Kedua, siswa menemukan contoh pemakaian bahasa yang sesuai kaidah maupun yang menyimpang dari kaidah, misalnya pemakaian tanda koma. Ketiga, siswa bersama guru merumuskan kaidah pemakaian bahasa yang benar .

\section{Pengukuran Hasil Pembelajaran Berba- sis Kompetensi Komunikatif}

Pengukuran kompetensi komunikatif diarahkan untuk mengukur bagaimana seseorang menggunakan bahasa dalam situasi kehidupan nyata dalam bentukbentuk yang gramatikal dan bermakna. Oleh karena itu, pengukuran pada pe- 
makaian bahasa secara produktif lebih tepat diarahkan pada kesesuaiannya dengan konteks pemakaian sekaligus kemampuan menghasilkan kalimat yang gramatikal. Adapun pada pemakaian bahasa secara reseptif ditekankan pada tingkat pemahaman komunikasi yang disampaikan melalui unsur-unsur kebahasaan yang menerapkan kaidah-kaidah kegramatikalan dari sederhana hingga kompleks sehingga menuntut audien membekali diri dengan penguasaan kaidah gramatika. Dengan dilatih mengidentifikasi kaidah pemakaian bahasa dalam teks yang sedang menjadi topik pembelajaran, memungkinkan tumbuhnya kepekaan siswa dalam mengenali bentukbentuk bahasa yang setipe, termasuk bentuk kesalahan berbahasa. Karena itu, pengukuran kompetensi komunikatif diarahkan untuk mengukur bagaimana seseorang menggunakan bahasa dalam situasi kehidupan nyata dalam bentukbentuk yang gramatikal dan bermakna.

\section{SIMPULAN}

Berdasarkan uraian di depan dirumuskan simpulan sebagai berikut ini. Pertama, (1) pembahasan kaidah bahasa umumnya tidak dilakukan pada pembelajaran keterampilan mendengarkan, membaca dan menulis dan (2) guru kesulitan dalam memilih dan menerapkan strategi, materi, dan pembagian waktu yang memungkinkan dilakukannya pembelajaran kaidah bahasa dan keterampilan berbahasa secara integratif. Kedua, kebutuhan guru mengadakan pembelajaran keterampilan berbahasa dan kaidah bahasa secara integratif meliputi: (1) strategi pembelajaran, (2) materi yang berupa contoh-contoh kesalahan bahasa pada aspek pilihan kata dan struktur kalimat, (3) media berupa rekaman bahasa lisan dan teks tertulis yang memuat model pemakaian bahasa yang bisa menjadi bahan analisis bagi siswa, dan (4) contoh lembar kerja siswa. Ketiga, kebutuhan siswa untuk me- ningkatkan penguasaan kaidah bahasa Indonesia adalah (1) pemberian koreksi dan contoh-contoh pemakaian bahasa yang salah, (2) bimbingan pada tahap penyuntingan dengan memberi tanda koreksi pada tulisan yang salah secara bertahap (tidak pada semua aspek kesalahan sekaligus), (3) pembahasan kaidah kalimat diperbanyak, dan (4) kesempatan berlatih menemukan kesalahan dan membetulkan kesalahan bahasa. Keempat, desain model pembelajaran keterampilan berbahasa dan kaidah bahasa secara integratif berbasis pendekatan "focus on form" dengan rambu-rambu sebagai berikut: (1) KD untuk situasi formal, (2) meliputi pelafalan kata, ejaan, pilihan kata, dan struktur kalimat sederhana, (3) penemuan kesalahan oleh siswa, (4) pembelajaran dilakukan dengan pendekatan proses, (5) strategi yang diterapkan antara lain processing instruction, interactional feedback, textual encahcement, task-based instruction, collaborative output tasks, discourse-based approach, dan (6) evaluasi terintegrasi dengan keterampilan yang dilatihkan.

Berkaitan dengan itu dapat diajukan saran sebagai berikut. Pertama, hendaknya pada kompetensi dasar yang relevan, dalam pembelajaran keterampilan berbahasa siswa dikenalkan dan dilatih menerapkan kaidah bahasa dalam aktivitas komunikasinya. Kedua, mengingat adanya dua tipe pendekatan focus on form, hendaknya penerapannya disesuaikan dengan kebutuhan.

\section{UCAPAN TERIMA KASIH}

Kegiatan Penelitian ini terlaksana atas bantuan dana dari Dikti melalui skema penelitian pengembangan dan pembinaan kelompok bidang keilmuan dengan dana Bantuan Operasional Perguruan Tinggi Negeri (BOPTN). Ucapan terima kasih disampaikan kepada pimpinan universitas, fakultas, jurusan, serta guru dan siswa SMP di Surakarta dan Karanganyar yang telah berpartisipasi aktif sebagai responden penelitian. 


\section{DAFTAR PUSTAKA}

Abdolmanafi, S.J. \& Branch, B.2010. “Effect of Focus on Form on the Learning of Relative Clauses in an EFL Context". Studies in Second Language Acquisition, 2(1): 27-39.

Basturkmen, H., Loewen, S. \& Ellis, R. 2002. "Focus on Form in the Communicative Classroom". Language Awareness, 11(1): 1- 13.

Celce-Murcia, M \& Elite, O. 2005. “Discourse-based Approaches: A New Framework for Second Language Teaching and Learning". Dalam E. Hinkel (ed.), Handbook of Research in Second Language Teaching and Learning. Mahwah, NJ: Lawrence Erlbaum Associates, 729-741.

Chen, Tsai-Yu. 2005. "In Search of an Effective Grammar Teaching Model". Modern Language Journal, 33 (3): 58-65.

Doughty, C. \& Williams, J. 1998. Focus on Form in Classroom Second Language Aquisition.Cambridge: Cambridge University Press.

Echevarria, J., Short, D., \& Powers, K. 2006. "School Reform and Standards-based Education: A Model for Englishlanguage Learners." Journal of Educational Research, 99 (4): 195-210.

Ellis, R. 2001. “Introduction: Investigating Form-focused Instruction". Language Learning 51 (Suppl1):1-46.

Ellis, R., Basturkmen, H. \& Loewen, S. 2001. "Focus on Form in the ESL Classroom". TESOL Quaterly, 35(3): 407432.

Fotos, S. 1996. "Integrating Grammar Instruction and Communicative Language Use through Grammar Consciousness-raising Tasks". TESOL Quarterly, 28, 323-351.

Hayashi, K. 1995. "Form-Focused Instruction and Second Language Profiency". RELC Journal, 26(1):95-117

Hendrickson, James. 1981. Error Analysis and Error Correction in Language Teach- ing. Singapore: RELC, Occasional Papers, 10.

Heo, Y. 2007. "The Effects of Grammar Instruction with Three Noticing Levels on ESL Learners'Grammar Test"..MA Thesis, Michigan State University.

Loewen, S. 2003. "Variation in the Frequency and Characteristics of Focus on Form". Language Teaching Research, 7(3): 315-345.

Myhill, D. \& Jones, S. 2007. "More Than Just Error Correction: Students' Perspectives on Their Revision Processes during Writing". Written Communication, 24: 323-343.

Nassaji, H. \& Fotos, S. 2004. "Current Developments in Research on the Teaching of Grammar". Annual Review of Applied Linguistics, 24, 126-145.

Nassaji, H. \& Cumming, A. 2000. "What is in ZPD: A Case Study of a Young ESL Student and Teacher Interacting through Dialogue Journals". Language Teaching Research, 4, 95-121.

Nurkamto, Joko. 2003. "Pendekatan Komunikatif dalam Pengajaran Bahasa". DalamJurnal Bahasa dan Seni FKIP UNS Spektrum,5 (10): 561-573

Sarigul, M. 2005. Effective Mistake Correction in Writings and an Aplication: The Maltepe University (Istambul) Project. Http://www.betaiatelf. hit.bg/pdfs/ papers Diakses 13 April 2010.

Sutama, I Made. 2008. “Pengintegrasian Pembelajaran Gramatika dalam Pembelajaran Menulis Bahasa Indonesia". Jurnal Pendidikan dan Pengajaran Bahasa, 2: 288-300.

Suyatno. 2010. Bahasa Indonesia sebagai Sarana Pengembangan Kualitas Sumber Daya Manusia. Naskah Pidato Pengukuhan Guru Besar Universitas Hamka Jakarta

VanPatten, B. 2002. "Processing Instruction: An Update". Language Learning, 52, 755-803. 